Srinivasan, Venkataramanujan; Pandi-Perumal, Seithikurippu R.; Moscovitch, Adam; Spence, Warren; Trakht Ilya; Brown, Gregory M.; Cardinali, Daniel P.

Potential use of melatonergic drugs in analgesia : mechanisms of action

Preprint del documento publicado en Brain Research Bulletin 81 362-371; 2010

Este documento está disponible en la Biblioteca Digital de la Universidad Católica Argentina, repositorio institucional desarrollado por la Biblioteca Central "San Benito Abad". Su objetivo es difundir y preservar la producción intelectual de la institución.

La Biblioteca posee la autorización del autor para su divulgación en línea.

Cómo citar el documento:

Se citará la versión editada:

Srinivasan V, Pandi-Perumal SR, Moscovitch A, et al. Potential use of melatonergic drugs in analgesia : mechanisms of action. Brain Res Bull. 2010;81. doi: 10.1016/j.brainresbull.2009.12.001 


\section{Potential use of melatonergic drugs in analgesia: mechanisms of action}

Venkataramanujam Srinivasan $\mathrm{PhD}$

Sri Sathya Sai Medical Educational and Research Foundation, Prsanthi Nilayam, Plot40 Kovai Thirunagar, Coimbatore-641014, INDIA

Phone number: +91-9486826359

sainivasan@yahoo.com

Seithikurippu R. Pandi-Perumal MSc

Somnogen Inc,

New York, NY 11418, USA.

Phone number 647-832-6177

sleepresearch@gmail.com

Adam Moscovitch, MD, fRCPC, DABSM, DABfM,

1 Codsel Avenue, Toronto, ON M3H 3V6, CANADA.

Phone number 416-291-0927

adam.moscovitch@csisleep.com

D. Warren Spence, MA,

1 Codsel Avenue, Toronto, ON M3H 3V6, CANADA.

Phone number 416-291-0927

dwspence@fastmail.fm

Ilya Trakht, $\mathrm{PhD}$

Division of Clinical Pharmacology and Experimental Therapeutics, Department of Medicine, College of Physicians and Surgeons of Columbia University,

630 West 168th Street - Rm \# BB813,

New York 10032, USA.

Phone number 212-305-7728

it8@columbia.edu

Gregory M. Brown MD, PhD

Professor Emeritus, Department of Psychiatry, University of Toronto

100 Bronte Rd,. Unit 422, Oakville, Ontario, CANADA L6L 6L5

Phone number 905-465-2941

gbrownpn@yahoo.ca

D.P. Cardinali MD PhD

Director, Department of Teaching \& Research,

Faculty of Medical Sciences, 
Pontificia Universidad Católica Argentina,

Av. Alicia Moreau de Justo 1500, 4o piso

1107 Buenos Aires, ARGENTINA.

Phone number +54 1143490200 ext 2310

danielcardinali@uca.edu.ar, danielcardinali@fibertel.com.ar

\section{Short Title:}

Melatonin and analgesia

\section{Abstract}

Melatonin is a remarkable molecule with diverse physiological functions. Some of its effects are mediated by receptors while other, like cytoprotection, seem to depend on direct and indirect scavenging of free radicals not involving receptors. Among melatonin's many effects, its antinociceptive actions have attracted attention. When given orally, intraperitoneally, locally, intrathecally or through intracerebroventricular routes, melatonin exerts antinociceptive and antiallodynic actions in a variety of animal models. These effects have been demonstrated in animal models of acute pain like the tail-flick test, formalin test or endotoxin-induced hyperalgesia as well as in models of neuropathic pain like nerve ligation. Glutamate, gamma-aminobutyric acid, and particularly, opioid neurotransmission have been demonstrated to be involved in melatonin's analgesia. Results using melatonin receptor antagonists support the participation of melatonin receptors in melatonin's analgesia. However, discrepancies between the affinity of the receptors and the very high doses of melatonin needed to cause effects in vivo raise doubts about the uniqueness of that physiopathological interpretation. Indeed, melatonin could play a role in pain through several alternative mechanisms including free radicals scavenging or nitric oxide synthase inhibition. The use of melatonin analogs like the $\mathrm{MT}_{1} / \mathrm{MT}_{2}$ agonist ramelteon, which lacks free radical scavenging activity, could be useful to unravel the mechanism of action of melatonin in analgesia. Melatonin has a promising role as an analgesic drug that could be used for alleviating pain associated with cancer, headache or surgical procedures.

\section{Keywords}

Nociception - Analgesia - Melatonin - Melatonin analogs - Opioid receptors - Melatonin receptors - Allodynia - Neuropathic pain 


\section{Introduction}

Melatonin (N-acetyl-5-methoxytryptamine) has been characterized as a remarkable molecule with diverse physiological functions, including the control of circadian rhythms [6,78], sleep regulation [17], enhancement of immunological functioning [22,84], free radical scavenging and antioxidant effects [119,139], inhibition of oncogenesis [15,134], mood regulation [106], vasoregulation [35] and regulation of seasonal reproductive activity $[80,121]$. Among that broad range of effects attributed to melatonin, its role in analgesia emerges as important because of its clinical implications.

Several early studies in mice $[16,29,68,73]$, hamsters [114], rats $[11,92,115,125]$ and man [33] showed that there is a circadian rhythm in pain perception. Furthermore, the pain threshold rhythm as measured by the tail flick test or by the hot plate test is abolished in the rat either by functional pinealectomy by light $[11,12,66]$ or by surgical pinealectomy [11]. Oral melatonin replacement in a physiological dosage reproducing the baseline $24 \mathrm{~h}$ rhythm of 6-sulphatoxymelatonin output restored the rhythm in both pressure-induced and heat-produced nociception that is abolished by light suppression $[65,66]$. Thus there is evidence that there is a physiologic antinociceptive effect of melatonin driving a circadian rhythm in pain perception. The antinociceptive effect of pharmacological doses of melatonin has therefore been examined in several animal models of pain perception (Table 1).

The pain modulatory role of melatonin has been also explored in human subjects $[19,23-25,46,54,63,89,94,97,100,109,112,113,118,135]$. The purpose of this review is to discuss the pharmacological basis for the antinociceptive role of melatonin and its analogs and the possible mechanisms by which they cause analgesia. For a recent review on the modulatory role of melatonin in pain see [5].

\section{Melatonin biosynthesis, metabolism and receptors}

In all mammals circulating melatonin is synthesized primarily in the pineal gland [26]. In addition, melatonin is also locally synthesized in various cells, tissues and organs including lymphocytes [20], human and murine bone marrow [28], the thymus [101], the gastrointestinal tract [18], skin [133] and, except in humans and rhesus monkeys, in the eyes [83]. In these tissues melatonin seems to plays either an autocrine or paracrine role.

Tryptophan serves as the precursor for the biosynthesis of melatonin [1]. It is taken up from the blood and is converted into serotonin via 5hydroxytryptophan. Serotonin is then acetylated to form Nacetylserotonin through the action of arylalkylamine $\mathrm{N}$-acetyltransferase (AANAT), one of the key enzymes in melatonin synthesis. $\mathrm{N}$ Acetylserotonin is then converted to melatonin by hydroxyindole-O- 
methyltransferase, which has been identified as a rate-limiting enzyme in the biosynthesis of melatonin [1].

Pineal melatonin biosynthesis is regulated by the light-dark cycle via the retinohypothalamic tract [95]. Special melanopsin-containing retinal ganglion cells [13] project to the suprachiasmatic nucleus of the hypothalamus. Other neuronal circuits include the hypothalamic paraventricular nucleus, the medial forebrain bundle and the reticular formation to influence intermediolateral horn cells of the spinal cord, which are the preganglionic neurons that innervate the superior cervical ganglion (SCG) [96]. The postganglionic fibers that arise from SCG regulate pineal melatonin biosynthesis by releasing norepinephrine (NE) at its pinealocyte receptor sites. $N E$, by interacting mainly with $\beta_{1^{-}}$, but also with $a_{1}$-adrenergic receptors in the pineal gland, activates the adenylyl cyclase-cyclic AMP pathway which in turn regulates expression of enzymes in melatonin biosynthetic pathway [1]. $a_{1}$-Adrenergic receptors potentiate $B$-adrenergic activity by producing a sharp increase in intracellular $\mathrm{Ca}^{2+}$ and activation of protein kinase $\mathrm{C}$ and of prostaglandin (PG) synthesis $[61,72,146]$. The subcellular mechanisms involved in the initiation and termination of AANAT activity have been elucidated in great detail (see for ref. [88]). Cyclic AMP stimulates AANAT expression and phosphorylation via protein kinase $A$, which also allows AANAT to be stabilized by binding of $14-3-3$ proteins $[47,129]$. The nocturnal exposure to bright light suppresses melatonin production immediately by degradation of pineal AANAT $[50,70]$.

Once formed melatonin is not stored within the pineal gland but it diffuses to the blood [141]. In those animals having a deep pineal, like the sheep, melatonin is released into the cerebrospinal fluid (CSF) via the pineal recess to reach high concentrations in the third ventricle, 20 to 30 times higher than that found in the blood [120].

Melatonin in blood is metabolized mainly in the liver where it is hydroxylated in the $\mathrm{C} 6$ position by cytochrome $\mathrm{P}_{450}$ monooxygenases (CYPA2 and CYP1A) [26]. It is then conjugated with sulfate to form 6sulphatoxymelatonin, the main melatonin metabolite found in urine. Melatonin is also deacetylated in neural tissues [57] and is also metabolized to form the kynuramine derivative $\mathrm{N}^{1}$-acetyl- $\mathrm{N}^{2}$ - formyl-5methoxykynuramine (AFMK) [44,58,60]. Interestingly this metabolite shares melatonin's antioxidant and anti-inflammatory properties [139]. Melatonin is also converted into cyclic 3-hydroxymelatonin in a process that directly scavenges two hydroxyl radicals [139]. Inasmuch as melatonin freely diffuses through all biological membranes, it exerts its actions in almost all cells in the body. Some of its actions are receptormediated while many others are receptor-independent.

Membrane-bound melatonin $\left(M_{1}, M_{2}\right)$ receptors have been identified and cloned from several tissues in the body [37]. These receptors belong to the superfamily of G-protein coupled receptors that 
contain the typical 7 transmembrane domains [122]. Activation of melatonin receptors in general leads to a decrease in cyclic AMP concentration. A third melatonin binding site, described initially as the "MT 3 receptor", has since been identified as quinone reductase 2 [103].

The distribution of melatonin receptors in lamina I- $\mathrm{V}$ and lamina $\mathrm{X}$ of the spinal cord was demonstrated by autoradiography [108]. By using reverse polymerase chain reaction techniques, transcripts of both $M T_{1}$ and $\mathrm{MT}_{2}$ melatonin receptors have been identified in both ventral and dorsal horns of the lumbar and thoracic regions of the spinal cord of rats [160]. It was thus hypothesized that melatonin exerts its analgesic effects through activation of melatonin receptors present in both spinal cord as well as in various brain regions.

A combination of reagents derived from the molecular clones and pharmacologic tools have revealed a considerable amount of information about the $M T_{1}$ and $M T_{2}$ receptors [8]. Many $G$ proteincoupled receptors (GPCRs), including the $M T_{1}$ and $M T_{2}$ receptors, exist in living cells as dimers. The relative propensity of the $\mathrm{MT}_{1}$ homodimer and $M T_{1} / M_{2}$ heterodimer formation are similar whereas that of the $M T_{2}$ homodimer is 3-4 fold lower [10,32]. It is of interest that the GPR 50 receptor, though lacking the ability to bind melatonin, abolishes high affinity binding of the $\mathrm{MT}_{1}$ receptor through heterodimerization $[76,77]$. Thus the GPR50 receptor may have a role in melatonin function by altering binding to the $\mathrm{MT}_{1}$ receptor.

Structural modifications of melatonin that seem to predispose to antagonist action include removal of the 5-methoxy group (e.g., luzindole, 2-benzyl N-acetyltryptamine) and the 4-phenyl substituted tetralines e.g. 4-phenyl-2-propionamidotetraline (4-P-PDOT) [36]. Luzindole was the first ligand to be identified as a competitive melatonin receptor antagonist and has since been used extensively in the field to validate melatonin receptor action. It is relatively receptor type nonselective $\left(\mathrm{MT}_{1} / \mathrm{MT}_{2}\right.$ affinity ratio $\left.=16 / 26\right)$ and was the first antagonist to be used for demonstrating that melatonin receptors are involved in the inhibition of dopamine release in rabbit retina and in the phase shift of circadian rhythms in rodents [36]. It must be noted that recent data indicate that luzindole is also an effective antioxidant in vitro [91] inhibiting the formation of 2,2'-azino-bis-(3-ethylbenzthiazoline-6-sulfonic acid (ABTS) radical cation by $80 \%$ at a concentration of $10 \mu \mathrm{M}$. Therefore some of the findings with luzindole can be unrelated to melatonin's actions on receptors.

4P-PDOT was the first available selective $M_{2}$ melatonin receptor antagonist and it has been used in many studies as a pharmacological tool to demonstrate the involvement of the $M T_{2}$ receptor type in physiological function $\left(\mathrm{MT}_{1} / \mathrm{MT}_{2}\right.$ affinity ratio $\left.=66 / 22000\right)$. In particular, it was employed to demonstrate the involvement of $M_{2}$ receptors in mediating phase advances of circadian rhythm of neuronal firing in the 
SCN circadian clock [62] and in inhibiting dopamine release in retina [38]. There are no published data available regarding actions of $M T_{1}$ selective antagonists on native tissues. Other receptor-mediated effects of melatonin may include nuclear binding to transcription factors such as ROR a 1, ROR a 2, and RZR $\beta$ that belong to the retinoic acid receptor superfamily [21,45]. Although their affinity is lower than that of the membrane receptors, they may have a role in paracrine and autocrine melatonin effects.

\section{Pain perception, hyperalgesia and allodynia}

When applied to the skin, muscle or viscera, various thermal or mechanical stimuli, or chemicals liberated from damaged tissues, evoke, besides pain, a constellation of autonomic behaviors, which collectively have been termed nociception. Nociception includes hyperalgesia (augmented sensitivity to painful stimuli) and allodynia (nociceptive responses to normally innocuous stimuli) $[53,64,126,127]$.

Tissue damage or inflammation release a variety of inflammatory mediators including reactive oxygen species (ROS), $\mathrm{PGE}_{2}$, leukotrienes, bradykinin, substance $P$, thromboxanes, inflammatory cytokines such as tumor necrosis factor (TNF)-a or interleukin (IL)-1 $\beta$, nerve growth factor, ATP and adenosine. Some of these agents directly activate nociceptors, while others release local algogenic agents. Algogenic substances sensitize nociceptive neurons, thereby enhancing neuronal excitability in pain transmission pathways and causing primary hyperalgesia.

The transmission of pain sensation by primary afferent fibers which have their central processes in the dorsal horn of the spinal cord has been shown to be influenced by several receptor subtypes. These include opioid ( $\mu$ and $\delta$ ), $a_{2}$ adrenoceptors, substance $P$, neurokinin, glutamate (AMPA and NMDA receptors) and neurotransmitters and neuromodulators such as substance $\mathrm{P}$, calcitonin gene-related peptide and neurokinin $[53,64,93,126,127,147]$.

Emerging evidence indicates that ROS are involved in chronic pain, including neuropathic and inflammatory pain $[27,81,128,137,140]$. Repeated painful stimulation causes an increase of oxidative stress and free radical generation as studied in the cerebral cortex of rats [123] and several studies have confirmed the association between increased free radical generation and hyperalgesia $[48,69,75,98,124,130,152]$. An exaggerated inflammatory response to tissue injury, neurogenic inflammation, ischemia and reperfusion injuries can all result in excessive production of ROS. Free radicals, in turn, can increase vascular permeability, release neuropeptides (i.e. substance P), enhance inflammation and cause further tissue damage $[27,81,128,137,140]$. ROS scavengers reduced pain behavior as well as hyper-responsiveness of spinal dorsal horn neurons [138], although there was little effect once pain was established [87]. 
Since melatonin and its endogenous metabolites (e.g. AFMK) are potent direct and indirect antioxidants [58,139], some of its analgesic activity may well depend on ROS scavenging. For example, a high dose of melatonin $(100 \mathrm{mg} / \mathrm{kg}$ ) given intraperitoneally (i.p.) to rats for five days brought about analgesic effects and reduced the level of thiobarbituric acid reactive substances (TBARS) in somatosensory cortex previously increased by painful stimulation [111]. Although the possible reason for the persisting increase in TBARS concentration in somatosensory cortex of the rats following the application of painful stimuli remains to be defined, the increasing neuronal metabolism occurring during pain perception could act as a trigger for intensifying the oxidative processes thereby increasing the free radical generation. Alternatively increased generation of kinins during painful stimuli, or activation of AMPA or NMDA receptors during persisting pain, could generate nitric oxide (NO) or peroxynitrite, an effect that can be blocked by melatonin [51]. Based on these considerations, it was suggested that the analgesic effect of melatonin could attributed to its free radical scavenging action [111]. That the nociceptive intensity is directly proportional to the amount of free radical generation has been confirmed in a recent study employing direct electron paramagnetic (spin) resonance, in which generation of free hydroxyl and nitroxide radicals was demonstrated following the application of nociceptive stimuli, an effect reduced after application of antioxidants [124].

Among the several ROS NO plays a pivotal role in critical actions involving several aspects of peripheral nerve function and disease $[128,140]$. NO offers important roles in "normal" afferent signaling of pain through the dorsal horn of the spinal cord and in autonomic control through nitrergic innervation. $\mathrm{NO}$ is generated during Wallerian degeneration of peripheral nerves following injury that bear on subsequent regenerative events. Through its actions on vasa nervorum, the blood supply to nerves, NO participates in microvascular changes following injury but also has direct roles in axon and myelin breakdown and "clearance" prior to regeneration $[128,140]$. During such processes, NO contributes to the development of neuropathic pain. Excessive local levels of NO during inflammation may damage axons and growth cones. Low-grade chronic rises in NO may also contribute toward peripheral nerve damage, or neuropathy in diabetes $[128,140]$. The preventing effect of melatonin on NO-induced damage has been documented in a variety of tissues (see for references $[9,43,71]$ ).

Other mechanisms which relate neuronal pathologies and free radicals induced damage have been suggested. It is now recognized that hyperalgesia, allodynia and pain perception all involve activation of glial cells in the spinal dorsal horn [162]. Activation of microglial cells in the dorsal horn in particular promotes neuropathic pain in a variety of nerve injury models such as spinal nerve ligation or dorsal rhizotomy [142]. Activation of microglial cells has been shown to result in the increase of 
purine receptors (P2X a family of ATP-gated ion channels that are permeable to $\mathrm{Ca}^{2+}$ ) and $\mathrm{p} 38$ MAPK receptors. $\mathrm{P} 2 \mathrm{X}_{4}$ receptor expression in the microglia augments progressively following nerve injury and parallels the development of allodynia. Pharmacological blockade of P2X 4 receptors or p38 MAPK receptors through the use of intrathecally administered antagonists has been shown to reverse mechanical allodynia, indicating that activation of microglia, P2X $\mathrm{X}_{4}$ and P38MAPK receptors are central to allodynia and neuropathic pain following nerve injury [148]. The effects of melatonin on glial cells are manifold and have been studied for years $[110,145]$.

\section{Melatonin's role in hyperalgesia and allodynia: evidence from animal models}

Melatonin's antinociceptive effect has been demonstrated by using several experimental models in mice and rats (Table 1). Administered through peripheral or central pathways melatonin, or some of its analogs, brought about a dose-dependent antinociception in models of acute $[42,55,73,79,99,105,111,136,143,151,153,154,157,158]$, inflammatory $[7,14,30,41,59,107,116,117,155]$ and neuropathic pain $[4,86,144,149]$. In all cases pharmacological amounts of melatonin were needed to produce effects.

Lakin and his co-workers were the first to show that the intraperitoneal (i.p.) administration of melatonin (30 mg/ $\mathrm{kg}$ ) produced antinociceptive effects in mice [73]. Whether melatonin's analgesic effect was time-dependent was evaluated in mice through the use of the hot plate procedure [55]. It was found that melatonin $(20-40 \mathrm{mg} / \mathrm{kg}$, i.p) exerted its maximal analgesic effect when administered in the late evening. Administration of the opiate antagonist naloxone or the central benzodiazepine (BZP) antagonist flumazenil blunted the analgesic response to melatonin, although they did not modify the pain threshold [55]. These blocking agents increased the latency of the hot plate responses induced by diazepam, thus showing that central opioid and BZP receptors are involved in the analgesic response.

In other studies the antinociceptive effect of melatonin was evaluated by using the hot water tail-flick test in rats. Melatonin, when injected intracerebroventricularly (i.c.v.) in three different doses (30, 60 or $120 \mathrm{mg} / \mathrm{kg}$ ) to groups of rats produced a dose-dependent antinociception [157]. In this study it was found that in rats that had been given larger doses of melatonin (60 or $120 \mathrm{mg} / \mathrm{kg}$ ), the effective antinociception started 15 min after melatonin administration, reached a peak after $30 \mathrm{~min}$ and lasted for $100 \mathrm{~min}$.

Studies in mice of melatonin's antinociceptive effects showed that these occurred without inducing physical dependence [159]. To elucidate the mechanism of melatonin's action, i.c.v. injection of naloxone $(10 \mu \mathrm{g})$ was given. It was found that melatonin's 
antinociceptive action (60 or $120 \mathrm{mg} / \mathrm{kg}$ i.p.) was antagonized by i.c.v. naloxone via an effect that started $10 \mathrm{~min}$ after naloxone administration and lasted for at least $45 \mathrm{~min}$. Since the changes were observed following the i.c.v. administration of naloxone, it was concluded that the CNS was the primary site for melatonin's analgesic effect [157]. In other studies, melatonin, when administered in doses 1,5 or $25 \mathrm{mg} / \mathrm{kg}$ i.p. or $0.25,0.5$ or $1 \mathrm{mg} / \mathrm{kg}$ i.c.v., produced significant increases in tail withdrawal latencies [79]. The increased latencies, which started $10 \mathrm{~min}$ after melatonin administration, reached the peak at $30 \mathrm{~min}$, and lasted for more than $70 \mathrm{~min}$. At all doses melatonin potentiated the antinociceptive actions of deltorphin-1, a $\delta$-opioid agonist, but not of the $\mu$-opioid agonist endomorphin-1 [79].

Endotoxin-induced hyperalgesia was used as a model for assessing melatonin's antinociceptive effects in inflammation. Intraplantar injection of lipopolysaccharide (LPS) reduced the threshold for nociceptive stimulus in the tail-flick and hot-plate tests [67]. LPS injection ( $5 \mu \mathrm{g}$ in $50 \mu \mathrm{l}$ of saline into the hind paws of mice) produced a significant decrease in the nociceptive threshold in the hot-plate and tail-flick tests, 6 and $10 \mathrm{~h}$ after endotoxin injection [116]. Melatonin (5 or $10 \mathrm{mg} / \mathrm{kg}$ ) significantly inhibited LPS-induced hyperalgesia at both time intervals. The attenuation of LPS-induced hyperalgesia by melatonin was not reversed by naltrexone $(4 \mathrm{mg} / \mathrm{kg})$. In vitro experiments showed that melatonin suppressed TNF-a release by LPS-activated macrophages. From these findings it was concluded that suppression of TNF-a could be one of the mechanisms by which melatonin attenuated LPS-induced hyperalgesia [116].

Electrical stimulation of the tail test is used as one of the models for evaluating pain perception, as that arising during carrageenen-induced inflammation in rats [41]. Melatonin $(0.5 \mathrm{mg}$ or $1 \mathrm{mg} / \mathrm{kg}$, i.p.) displayed antinociceptive effects after the electrical stimulation in the rat tail test, increasing the nociceptive thresholds by $29.6 \%$ and $39.5 \%$ respectively. Melatonin at a dose of $0.5 \mathrm{mg} / \mathrm{kg}$ also increased the antinociceptive effect of indomethacin and reduced the carrageenan-induced edema in a dose dependent manner thus demonstrating that melatonin has a significant anti-inflammatory effect [41]. Locally applied melatonin at paw in a carrageenan-induced paw edema model in rats inhibited the inflammatory response via an inhibitory effect on expression of NO synthase [30]. In another model of inflammatory pain melatonin (150$600 \mathrm{\mu g} / \mathrm{paw}$ ) caused a dose-dependent antinociception which was reversed by the antagonism of the NO-cyclic GMP-protein kinase G-K+ channel pathway [59].

NMDA receptors in the spinal cord play a major role in pain transmission at the dorsal horn level and they are involved in the potentiation of nociceptive synaptic transmission in the spinal cord, a phenomenon known as "wind-up" $[64,126,128]$. In this process there is a repetitive increase in the response of dorsal horn neurons due to increase 
in the intensity of C-fiber stimulation. Using C-fiber stimulation to initiate the spinal wind-up effect, Laurido et al. found that different doses of melatonin $(1.25 \mathrm{mg}, 2.5,5.0$ or $10 \mathrm{mg} / \mathrm{kg}$ ) produced dose-dependent decreases of spinal cord wind-up, with the highest dose resulting in a complete suppression of wind- up activity [74]. The authors suggested that melatonin-induced spinal wind-up may have been due to melatonin's intracellular influence on NMDA receptor dependent NO generating pathways.

Both the antinociceptive and antiallodynic effects of melatonin have been studied in experimentally-induced diabetic rats [7]. A formalin test was used as a model for evaluation of pain perception. This pain model produced two nociceptive responses. The first phase occurs within 5 min after formalin injection and involves the activation of $\mathrm{C}$-fibers and the release of substance $P$ and bradykinin [132]. The second response begins after a brief quiescent period and is due to activation of NMDA receptors with increased release of $\mathrm{Ca}^{2+}$, histamine, PGs and bradykinin [104]. Oral administration of melatonin $(150 \mathrm{mg} / \mathrm{kg})$ significantly reduced formalin-induced nociceptive behavior and has antiallodynic effects at 20 and 60 min post-treatment. This study was the first to describe melatonin's antinociceptive and antiallodynic effects in streptozotocin-injected diabetic rats [7].

Nerve injury results in abnormal pain perception, known as neuropathic pain, which is associated with hyperalgesia and allodynia. The analgesic effects of melatonin on mice subjected to tight ligation of sciatic nerve was studied by using the withdrawal threshold test (for assessing mechanical allodynia) and withdrawal latencies (for assessing thermal analgesia) [144]. Melatonin at the highest doses (120 mg/kg i.p. and $0.1 \mathrm{nmol}$ i.c.v.) reduced paw withdrawal latencies in response to radiant heat stimulation of the injured hind paw compared to corresponding values of normal rats. When mechanical allodynia was tested, neither i.p. nor i.c.v. melatonin had any effect on the withdrawal thresholds to von Frey hairs compared to the respective injection baseline value. From these findings it was concluded that that both i.c.v. and i.p. melatonin injections at high doses block thermal hyperalgesia in neuropathic mice but did not block mechanical allodynia. Coadministration of both L-arginine and naloxone reduced the effects of melatonin suggesting that melatonin's effect on thermal hyperalgesia was mediated at least in part by the L-arginine-NO-pathway and the opioidergic system [144].

Administration of melatonin into the anterior cingulate cortex contralateral to peripheral nerve injury prevented exacerbation of mechanical allodynia with a concurrent improvement of depression-like behavior in Wistar-Kyoto rats [161]. In the same experimental model the effect of the individual versus combined treatment of melatonin and/or the NMDA receptor antagonist dextromethorphan was assessed [149]. Dextromethorphan alone was effective in reducing thermal hyperalgesia 
at three tested doses $(15,30$ or $60 \mathrm{mg} / \mathrm{kg})$ and reduced mechanical allodynia only at high doses (30 or $60 \mathrm{mg} / \mathrm{kg}$ ). By comparison, administration of melatonin alone was effective in reducing thermal hyperalgesia only at the highest dose $(120 \mathrm{mg} / \mathrm{kg})$ tested but failed to reverse allodynia at all three tested doses $(30,60$ and $120 \mathrm{mg} / \mathrm{kg})$. The combined i.p. administration of melatonin $(30 \mathrm{mg} / \mathrm{kg})$ and dextromethorphan $(15 \mathrm{mg} / \mathrm{kg})$ effectively reversed both thermal hyperalgesia and mechanical allodynia indicating that the combination of melatonin with a NMDA receptor antagonist can be more effective than either drug alone for the treatment of neuropathic pain [150].

\section{Involvement of melatonin receptors in antinocic eption}

The possibility that melatonin receptors could be involved in melatonin's analgesic action was studied by using the unspecific $M T_{1} / M_{2}$ receptor antagonist luzindole $[79,86,105,151,155,158]$ or the specific $M_{2}$ antagonists 4-P-PDOT $[4,143,155]$ and K185 (N-butanoyl-2(5,6,7-trihydro-11-methoxybenzo

$[3,4]$ cyclohept $[2,1-$ a]indol-13yl)ethanamine) [7]. Melatonin administration in different doses i.p. (30, 60 or $120 \mathrm{mg} / \mathrm{kg}$ ) caused antinociception in a dose-dependent manner. It was found that the i.c.v. injection of $50 \mu \mathrm{g}$ of luzindole antagonized completely melatonin's antinociceptive effect. As a hypothesis it was proposed that melatonin reduces the excitability of pain transmitting dorsal horn neurons via hyperpolarization caused through its binding to membrane melatonin receptors [74].

The possible participation of melatonin receptors in melatonin induced antiallodynia was assessed in a rat model of neuropathic pain, i.e., the ligation of L5/L6 spinal nerves [4]. Intrathecal (3-100 $\mu \mathrm{g}$ ) or oral $(37.5$ - $300 \mathrm{mg} / \mathrm{kg}$ ) administration of melatonin decreased tactile allodynia induced by spinal nerve ligation. Intrathecal administration of luzindole (1-100 $\mu \mathrm{g})$ significantly diminished in a dose-dependent manner the antiallodynic effect of melatonin. Similarly oral $(0.01-1 \mathrm{mg} / \mathrm{kg})$ or intrathecal $(0.1-10 \mu \mathrm{g})$ administration of the highly selective $\mathrm{MT}_{2}$ receptor antagonist 4P-PDOT diminished the antiallodynic effect of melatonin. Subcutaneous $(1 \mathrm{mg} / \mathrm{kg})$ or intrathecal $(0.5-50 \mu \mathrm{\mu g})$ treatment with naltrexone diminished the antiallodynic effect induced by oral or intrathecal melatonin [4]. These data suggested that $\mathrm{MT}_{2}$ receptors present in spinal cord and opioid receptors mediate the antiallodynic effect of melatonin.

The mechanism for antinociceptive and antiallodynic effects of melatonin were examined in streptozotocin-induced diabetic rats by using the $\mathrm{MT}_{2}$ receptor blocking agent K185 [7]. It was found that melatonin's antinociceptive effects were diminished by prior administration of $\mathrm{K} 185$ (0.2 to $2 \mathrm{mg} / \mathrm{kg}$ s.c.). This demonstrated again that $M T_{2}$ receptors present in the spinal cord are involved in melatonininduced antinociception. The possible participation of $\delta$-opioid receptors 
was assessed by using naltrexone ( $\delta$ receptor antagonist) and 5guanidinonaltrinole (k-opioid receptor antagonist). It was found that naltrexone (but not 5-guanidinonaltrindole) partially reduced the melatonin induced antinociception, thus demonstrating the possible participation of $\delta$, but not $\mathrm{k}$, opioid receptors in the antinociceptive effect of melatonin in diabetic rats [7].

A number of melatonin analogs have been developed which are more potent than melatonin in binding to $M T_{1}$ and $M T_{2}$ melatonin receptors [49]. Among these, 2- bromomelatonin (substitution with bromine at the 2 indole position of melatonin) has been shown to be 10 times more effective in binding to melatonin receptors [39]. The analgesic properties of 2-bromomelatonin was tested in Sprague-Dawley rats [99]. 2-Bromomelatonin i.p. injected at 30 and $45 \mathrm{mg} / \mathrm{kg}$ doses resulted in significant antinociceptive effects as assessed by the loss of response to tail clamping. The loss of response occurred in $100 \%$ of rats after 1 and $2 \mathrm{~min}$ of a bolus injection of $45 \mathrm{mg} / \mathrm{kg}$ of 2-bromomelatonin [99]. The intrathecal administration of 2-bromomelatonin was effective to decrease mechanical nociception an effect blocked by intrathecal naloxone or luzindole injection [105].

The effect of 6-chloromelatonin on capsaicin-induced mechanical allodynia and hyperalgesia was evaluated in Sprague-Dawley rats [143]. Intradermal injection of capsaicin caused long-lasting primary and secondary allodynia [52]. The increase in paw withdrawal frequency induced by capsaicin was significantly reduced or blocked by the prior Intrathecal injection of the melatonin agonist 6-chloromelatonin [143]. The effect of Intrathecal 6-chloromelatonin was blocked by the intrathecal administration of 4P-PDOT.

The effect of pyridomelatonin analogs on the hot plate latency test and acetic acid induced abdominal writhes was evaluated by Elmegeed et al. [42]. The activity of the tricyclic pyrrolo-and pyridoindole derivatives $3,5,9 a$ and 12 was compared with that of melatonin on thermal and visceral pain and inflammation. Hot plate latency was increased by the administration of all the compounds when assessed $1 \mathrm{~h}$ or $2 \mathrm{~h}$ after administration. Although compounds 3 and 5 were as effective as melatonin, the effect of compound 12 was significantly more prolonged. All these compounds also significantly reduced the number of abdominal writhes induced in mice by i.p. injection of acetic acid [42]. Compounds 5 and 12 were found to be most potent in this aspect, i.e., they inhibited the number of abdominal writhes by 69 and 81 $\%$ as compared to controls. Compounds $3,9 a$ and melatonin inhibited the number of abdominal writhes by 24,41 and $55 \%$ respectively. The authors concluded that the pyrrole moiety of the compounds 5 and 12 acts potently as an antinociceptive agent and that fusion of pyrrole ring to melatonin moiety were beneficial in increasing the antinociceptive action [42]. 
A major question concerning the involvement of melatonin receptors in the analgesic effect of melatonin refers to the doses of melatonin needed to produce effects. Although, as noted in the introduction, there is evidence for a physiologic role of melatonin in modulating the circadian rhythm in nociception, the lowest effective doses employed (in the $\mathrm{mg}$ range) result in melatonin blood levels several orders of magnitude above the concentration necessary to activate melatonin receptors. It must be noted, however, that in many cases the effect of melatonin could be blocked by antagonists like luzindole or 4P-PDOT (Table 1).

In view of the very prominent role that ROS have in pain and of the direct and indirect antioxidant activity of melatonin, the possibility that melatonin could via suppression of ROS production should be considered. There is scarce information on the ROS scavenging properties of many of the melatonin analogs studied. One exception is ramelteon, the $M T_{1} / M_{2}$ agonist approved by the FDA by its sleep promoting activity in insomnia in the elderly, which has been demonstrated to be ineffective as ROS scavenger [90].

\section{Melatonin and opioid system in analgesia}

Earlier studies suggested that melatonin exerts its antinociceptive actions by acting through opiate and/or BZP pathways $[55,73,136]$. Numerous reports have confirmed the interaction between melatonin and the opioid system [34,79]. Interestingly, this interrelationship is manifold: studies of the distribution of opioid receptors have revealed that $\delta$-opioid receptors are the only opioid receptors that are present in maximum concentrations in the pineal gland $[3,56]$. Through $\delta$-opioid receptors the activity of AANAT is stimulated, being an event responsible for enhancing pineal melatonin production. Moreover, naloxone administration has been found to decrease the nocturnal maximum in pineal melatonin content of rats, thus confirming the physiological role of opioid receptors in vivo in pineal melatonin control [82].

Fluctuations in pain threshold can be correlated with simultaneous fluctuations in plasma $\beta$-endorphin immunoreactivity and melatonin release [12]. The antinociceptive effect of melatonin is blunted by the opiate antagonist naloxone $[55,73,86,105,136,151,153,157]$.

Melatonin's pharmacodynamics during analgesia induction was studied by defining the effects of melatonin receptor agonists and antagonists on the opioid receptor binding and release of endogenous opioids such as $\beta$-endorphin. Administration of melatonin causes the release of $\beta$-endorphin, a potent opioid in humans [156]. The release of $\beta$-endorphin in the periaqueductal gray perfusate of rats after melatonin administration was found to produce a significant increase of pain threshold in these animals, thus suggesting that melatonin influences pain perception via $\beta$-endorphin release [156]. 
Shavali et al. explored melatonin's effect on the opioid system by studying the mechanism through which it increased $\beta$-endorphin release from mouse pituitary AtT-20 cells in culture [131]. The authors speculated that melatonin's antinociceptive action could be due to its binding to opioid receptors subtypes rather than to binding to its own receptors.

Indeed some evidence has been provided that melatonin interacts with the opioid peptides [2,85]. Melatonin is synthesized following acute pain episodes in humans [102], the function of which may be to modulate fluctuations in opioid receptor expression and levels of betaendorphin [12]. The relationship of melatonin with the opioidergic system is complex and not completely understood, although there is evidence that it has mixed opioid receptor agonist-antagonist activity [40]. Collectively, these findings lend support to the existence of a "melatoninopioid axis" [12].

Dai et al. used the mouse tail flick test to study the effect of melatonin on the development of antinociceptive tolerance to different types of opioid receptor agonists [31]. The investigators found that melatonin had no inhibitory effect on tolerance induced by $\mu$-opioid receptor agonist (endomorphin 1) but exerted an inhibitory effect on tolerance induced by $\delta$-opioid receptor agonist (deltotrophin). These effects were shown to be antagonized by luzindole. These findings support the conclusion that melatonin interferes with the neural mechanisms involved in the development of tolerance to deltoid opioid analgesia via interaction with melatonin receptors [31].

The antinociceptive action of melatonin $(100 \mathrm{mg} / \mathrm{kg}$, i.p.) on glutamate-induced nociception in mice was completely blocked by i.p. pretreatment of animals with the opioid receptor antagonist naloxone (1 $\mathrm{mg} / \mathrm{kg})$, the $5-\mathrm{HT}_{2 \mathrm{~A}}$ receptor antagonist ketanserin $(1 \mathrm{mg} / \mathrm{kg})$, the dopaminergic $D_{2}$ receptor antagonist sulpiride $(50 \mathrm{mg} / \mathrm{kg})$, the $a_{1}$ adrenoceptor antagonist prazosin, the $\mathrm{MT}_{1} / \mathrm{MT}_{2}$ receptor antagonist luzindole $(0.15 \mathrm{mg} / \mathrm{kg})$ or L-arginine $(600 \mathrm{mg} / \mathrm{kg})$ [86]. From their findings the authors concluded that melatonin induces antinociception by interacting with both peripheral and central melatonin receptors through effects modulated by opioidergic, serotonergic, dopaminergic and adrenergic receptors as well as by the L-arginine-nitric oxide pathway.

Other aspects of the mechanism of interaction between melatonin and opioid peptides in pain regulation was investigated by using the tailflick assay in mice to evaluate the hyperalgesic effect of orphanin $F Q /$ nociceptin (NC), a member of opioid peptide family [151]. Luzindole and naloxone were used to assess the possible mechanisms of pain modulation by melatonin. When mice were co-injected with melatonin i.c.v. (5, 10 or $50 \mu \mathrm{g} /$ mouse) and $\mathrm{NC}(10 \mu \mathrm{g} /$ mouse) there was a complete absence of the hyperalgesic effect. Injection of luzindole or naloxone $(10 \mathrm{\mu g} / \mathrm{mice})$ inhibited the reversal effect on NC-induced hyperalgesia by melatonin. These findings were interpreted to support 
the conclusion that melatonin's reversal of NC-induced hyperalgesia was mediated by melatonin receptors and promotion of the release of $\beta$-endorphin [151].

\section{Conclusions}

Melatonin has been shown to exert antinociceptive and antiallodynic actions in a variety of experimental models in animals. Induction of pain involves the release of several pro-inflammatory mediators like cytokines and the activation of a number of neurotransmitter receptor sites present both in the spinal cord and brain. A molecule like melatonin that is effective in: (i) controlling the release of pro-inflammatory mediators; (ii) inhibiting the activation of receptors involved in pain perception present at spinal cord; (iii) inhibiting receptor activation in brain regions involved in pain perception: (iv) promoting sleep, can be extremely effective for controlling/inhibiting pain perception. Melatonin fulfills all these criteria and hence for all practical purposes it could serve as an effective drug in controlling pain perception.

The available evidence demonstrates that melatonin exerts these actions by acting through the opioid system perhaps via melatonin receptors present in the spinal cord and in the brain. There is evidence for involvement of the pineal gland and for a modulatory effect of melatonin on the circadian rhythm of nociception. Nonetheless high doses of melatonin are required to produce major analgesic effects. Thus there may be two different mechanisms involved. Perhaps the circadian rhythm of nociception is related to actions on melatonin receptors while the major analgesic effects are due to non-receptor actions. Therefore, the possibility that melatonin could act via a receptor-independent mechanism like suppression of ROS production should be considered. Further studies on $M T_{1} / M_{2}$ agonists such as ramelteon, which lacks free radical scavenger properties, could be useful to answer this query.

The potential value of melatonin's antinociceptive and antiallodynic action can be appreciated by clinical studies undertaken in patients suffering from pain due to inflammation, pain occurring during headache, pain of cancer patients, neuropathic pain and fibromyalgia $[19,23-25,46,54,63,89,94,97,100,109,112,113,118,135]$. The animal models of pain perception suggest that melatonin and its analogs have a promising role as a novel antinociceptive therapy. 


\section{References}

[1] K. Ackermann, J.H. Stehle, Melatonin synthesis in the human pineal gland: advantages, implications, and difficulties, Chronobiol. Int. 23 (2006) 369-379.

[2] D. Acuña-Castroviejo, G. Escames, M. Macias, H.A. Munoz, C.A. Molina, M. Arauzo, R. Montes, Cell protective role of melatonin in the brain, J. Pineal Res. 19 (1995) 57-63.

[3] V.J. Aloyo, Identification and characterization of delta opioid binding sites in the bovine pineal, J. Pharmacol. Exp. Ther. 262 (1992) 292-297.

[4] M. Ambriz-Tututi, V. Granados-Soto, Oral and spinal melatonin reduces tactile allodynia in rats via activation of $\mathrm{MT}_{2}$ and opioid receptors, Pain 42 (2007) 12851292.

[5] M. Ambriz-Tututi, H.I. Rocha-Gonzalez, S.L. Cruz, V. Granados-Soto, Melatonin: a hormone that modulates pain, Life Sci. 84 (2009) 489-498.

[6] S.M. Armstrong, Melatonin and circadian control in mammals, Experientia 45 (1989) 932-938.

[7] R. Arreola-Espino, H. Urquiza-Marin, M. Ambriz-Tututi, C.I. Araiza-Saldana, N.L. Caram-Salas, H.I. Rocha-Gonzalez, T. Mixcoatl-Zecuatl, V. Granados-Soto, Melatonin reduces formalin-induced nociception and tactile allodynia in diabetic rats, Eur. J. Pharmacol. 577 (2007) 203-210.

[8] V. Audinot, A. Bonnaud, L. Grandcolas, M. Rodriguez, N. Nagel, J.P. Galizzi, A. Balik, S. Messager, D.G. Hazlerigg, P. Barrett, P. Delagrange, J.A. Boutin, Molecular cloning and pharmacological characterization of rat melatonin $\mathrm{MT}_{1}$ and $\mathrm{MT}_{2}$ receptors, Biochem. Pharmacol. 75 (2008) 2007-2019.

[9] S. Aydogan, M.B. Yerer, A. Goktas, Melatonin and nitric oxide, J. Endocrinol. Invest. 29 (2006) 281-287.

[10] M.A. Ayoub, C. Couturier, E. Lucas-Meunier, S. Angers, P. Fossier, M. Bouvier, R. Jockers, Monitoring of ligand-independent dimerization and ligand-induced conformational changes of melatonin receptors in living cells by bioluminescence resonance energy transfer, J. Biol. Chem. 277 (2002) 2152221528.

[11] A. Bar-Or, G.M. Brown, Pineal involvement in the diurnal rhythm of nociception in the rat, Life Sci. 44 (1989) 1067-1075.

[12] T. Barrett, S. Kent, N. Voudouris, Does melatonin modulate beta-endorphin, corticosterone, and pain threshold?, Life Sci. 66 (2000) 467-476.

[13] D.M. Berson, Phototransduction in ganglion-cell photoreceptors, Pflugers Arch. 454 (2007) 849-855.

[14] D. Bilici, E. Akpinar, A. Kiziltunc, Protective effect of melatonin in carrageenaninduced acute local inflammation, Pharmacol. Res. 46 (2002) 133-139.

[15] D.E. Blask, L.A. Saver, R.T. Dauchy, Melatonin as a chronobiotic/anticancer agent: cellular, biochemical, and molecular mechanisms of action and their implications for circadian-based cancer therapy, Curr. Top. Med. Chem. 2 (2002) 113-132.

[16] R.L. Bornschein, R.S. Crockett, R.P. Smith, Diurnal variations in the analgesic effectiveness of morphine in mice, Pharmacol. Biochem. Behav. 6 (1977) 621626.

[17] A. Brzezinski, M.G. Vangel, R.J. Wurtman, G. Norrie, I. Zhdanova, A. Ben Shushan, I. Ford, Effects of exogenous melatonin on sleep: a meta-analysis, Sleep Med. Rev. 9 (2005) 41-50.

[18] G.A. Bubenik, Gastrointestinal melatonin: localization, function, and clinical relevance, Dig. Dis. Sci. 47 (2002) 2336-2348.

[19] M. Camilleri, V. Andresen, Current and novel therapeutic options for irritable bowel syndrome management, Dig. Liver Dis. in press

[20] A. Carrillo-Vico, J.R. Calvo, P. Abreu, P.J. Lardone, S. Garcia-Maurino, R.J. Reiter, J.M. Guerrero, Evidence of melatonin synthesis by human lymphocytes and its physiological significance: possible role as intracrine, autocrine, and/or paracrine substance, FASEB J. 18 (2004) 537-539. 
[21] A. Carrillo-Vico, A. Garcia-Perganeda, L. Naji, J.R. Calvo, M.P. Romero, J.M. Guerrero, Expression of membrane and nuclear melatonin receptor mRNA and protein in the mouse immune system, Cell Mol. Life Sci. 60 (2003) 2272-2278.

[22] A. Carrillo-Vico, R.J. Reiter, P.J. Lardone, J.L. Herrera, R. Fernandez-Montesinos, J.M. Guerrero, D. Pozo, The modulatory role of melatonin on immune responsiveness, Curr. Opin. Investig. Drugs 7 (2006) 423-431.

[23] W. Caumo, R. Levandovski, M.P. Hidalgo, Preoperative anxiolytic effect of melatonin and clonidine on postoperative pain and morphine consumption in patients undergoing abdominal hysterectomy: a double-blind, randomized, placebo-controlled study, J. Pain 10 (2009) 100-108.

[24] W. Caumo, F. Torres, N.L. Moreira, Jr., J.A. Auzani, C.A. Monteiro, G. Londero, D.F. Ribeiro, M.P. Hidalgo, The clinical impact of preoperative melatonin on postoperative outcomes in patients undergoing abdominal hysterectomy, Anesth. Analg. 105 (2007) 1263-1271-

[25] G. Citera, M.A. Arias, J.A. Maldonado-Cocco, M.A. Lazaro, M.G. Rosemffet, L.I. Brusco, E.J. Scheines, D.P. Cardinalli, The effect of melatonin in patients with fibromyalgia: a pilot study, Clin Rheumatol. 19 (2000) 9-13.

[26] B. Claustrat, J. Brun, G. Chazot, The basic physiology and pathophysiology of melatonin, Sleep Med. Rev. 9 (2005) 11-24.

[27] G.L. Close, T. Ashton, A. McArdle, D.P. Maclaren, The emerging role of free radicals in delayed onset muscle soreness and contraction-induced muscle injury, Comp. Biochem. Physiol. A Mol. Integr. Physiol. 142 (2005) 257-266.

[28] A. Conti, S. Conconi, E. Hertens, K. Skwarlo-Sonta, M. Markowska, J.M. Maestroni, Evidence for melatonin synthesis in mouse and human bone marrow cells, J. Pineal Res. 28 (2000) 193-202.

[29] R.S. Crockett, R.L. Bornschein, R.P. Smith, Diurnal variation in response to thermal stimulation: mouse-hotplate test, Physiol. Behav. 18 (1977) 193-196.

[30] S. Cuzzocrea, B. Zingarelli, E. Gilad, P. Hake, A.L. Salzman, C. Szabo, Protective effect of melatonin in carrageenan-induced models of local inflammation: relationship to its inhibitory effect on nitric oxide production and its peroxynitrite scavenging activity, J. Pineal Res. 23 (1997) 106-116.

[31] X. Dai, S.G. Cui, S.R. Li, Q. Chen, R. Wang, Melatonin attenuates the development of antinociceptive tolerance to delta-, but not to mu-opioid receptor agonist in mice, Behav. Brain Res. 182 (2007) 21-27.

[32] A.M. Daulat, P. Maurice, C. Froment, J.L. Guillaume, C. Broussard, B. Monsarrat, P. Delagrange, R. Jockers, Purification and identification of $G$ protein-coupled receptor protein complexes under native conditions, Mol. Cell Proteomics 6 (2007) 835-844.

[33] G.C. Davis, M.S. Buchsbaum, W.E. Bunney, Jr., Naloxone decreases diurnal variation in pain sensitivity and somatosensory evoked potentials, Life Sci. 23 (1978) 1449-1459.

[34] E. Dhanaraj, K.V. Nemmani, P. Ramarao, Melatonin inhibits the development of tolerance to $\mathrm{U}-50,488 \mathrm{H}$ analgesia via benzodiazepine-GABA $A_{A}$ ergic mechanisms, Pharmacol. Biochem. Behav. 79 (2004) 733-737.

[35] S. Doolen, D.N. Krause, M.L. Dubocovich, S.P. Duckles, Melatonin mediates two distinct responses in vascular smooth muscle, Eur. J. Pharmacol. 345 (1998) 67-69.

[36] M.L.Dubocovich, D.P.Cardinali, P.Delagrange, D.N.Krause, D.Strosberg, D.Sugden, F.D.Yocca, Melatonin receptors. In IUPHAR (Ed.), The IUPHAR Compendium of Receptor Characterization and Classification, 2nd. Edition IUPHAR Media, London, 2000, pp. 271-277.

[37] M.L. Dubocovich, M. Markowska, Functional $M T_{1}$ and $M T_{2}$ melatonin receptors in mammals, Endocrine 27 (2005) 101-110.

[38] M.L. Dubocovich, M.I. Masana, S. lacob, D.M. Sauri, Melatonin receptor antagonists that differentiate between the human Mel ${ }_{1}$ and Melıb recombinant subtypes are used to assess the pharmacological profile of the rabbit retina $M L_{1}$ presynaptic heteroreceptor, Naunyn Schmiedebergs Arch. Pharmacol. 355 (1997) 365-375. 
[39] E. Duranti, B. Stankov, G. Spadoni, A. Duranti, V. Lucini, S. Capsoni, G. Biella, F. Fraschini, 2-Bromomelatonin: synthesis and characterization of a potent melatonin agonist, Life Sci. 51 (1992) 479-485.

[40] M. Ebadi, P. Govitrapong, P. Phansuwan-Pujito, F. Nelson, R.J. Reiter, Pineal opioid receptors and analgesic action of melatonin, J. Pineal Res. 24 (1998) 193200.

[41] S.M. El Shenawy, O.M. Abdel-Salam, A.R. Baivomy, S. El batran, M.S. Arbid, Studies on the anti-inflammatory and anti-nociceptive effects of melatonin in the rat, Pharmacol. Res. 46 (2002) 235-243.

[42] G.A. Elmegeed, A.R. Baiuomy, O.M. Abdel-Salam, Evaluation of the antiinflammatory and anti-nociceptive activities of novel synthesized melatonin analogues, Eur. J. Med. Chem. 42 (2007) 1285-1292.

[43] G. Escames, D. Acuña-Castroviejo, L.C. Lopez, D.X. Tan, M.D. Maldonado, M. Sanchez-Hidalgo, J. Leon, R.J. Reiter, Pharmacological utility of melatonin in the treatment of septic shock: experimental and clinical evidence, J. Pharm. Pharmacol. 58 (2006) 1153-1165.

[44] G. Ferry, C. Ubeaud, P.H. Lambert, S. Bertin, F. Coge, P. Chomarat, P. Delagrange, B. Serkiz, J.P. Bouchet, R.J. Truscott, J.A. Boutin, Molecular evidence that melatonin is enzymatically oxidized in a different manner than tryptophan: investigations with both indoleamine 2,3-dioxygenase and myeloperoxidase, Biochem. J. 388 (2005) 205-215.

[45] T.W. Fischer, M.A. Zmijewski, B. Zbytek, T.W. Sweatman, R.M. Slominski, J. Wortsman, A. Slominski, Oncostatic effects of the indole melatonin and expression of its cytosolic and nuclear receptors in cultured human melanoma cell lines, Int. J. Oncol. 29 (2006) 665-672.

[46] J.J. Gagnier, The therapeutic potential of melatonin in migraines and other headache types, Altern. Med. Rev. 6 (2001) 383-389.

[47] S. Ganguly, J.L. Weller, A. Ho, P. Chemineau, B. Malpaux, D.C. Klein, Melatonin synthesis: 14-3-3-dependent activation and inhibition of arylalkylamine Nacetyltransferase mediated by phosphoserine-205, Proc. Natl. Acad. Sci. U.S.A. 102 (2005) 1222-1227.

[48] X. Gao, H.K. Kim, J.M. Chung, K. Chung, Reactive oxygen species (ROS) are involved in enhancement of NMDA-receptor phosphorylation in animal models of pain, Pain 131 (2007) 262-271.

[49] P.J. Garratt, A. Tsotinis, Synthesis of compounds as melatonin agonists and antagonists, Mini. Rev. Med. Chem. 7 (2007) 1075-1088.

[50] J.A. Gastel, P.H. Roseboom, P.A. Rinaldi, J.L. Weller, D.C. Klein, Melatonin production: proteasomal proteolysis in serotonin $\mathrm{N}$-acetyltransferase regulation, Science 279 (1998) 1358-1360.

[51] E. Gilad, S. Cuzzocrea, B. Zingarelli, A.L. Salzman, C. Szabo, Melatonin is a scavenger of peroxynitrite, Life Sci. 60 (1997) L169-L174.

[52] H.D. Gilchrist, B.L. Allard, D.A. Simone, Enhanced withdrawal responses to heat and mechanical stimuli following intraplantar injection of capsaicin in rats, Pain 67 (1996) 179-188.

[53] P.J. Goadsby, A.R. Charbit, A.P. Andreou, S. Akerman, P.R. Holland, Neurobiology of migraine, Neuroscience 161 (2009) 327-341.

[54] I. Gogenur, B. Kucukakin, T. Bisgaard, V. Kristiansen, N.C. Hjortso, D.J. Skene, J. Rosenberg, The effect of melatonin on sleep quality after laparoscopic cholecystectomy: a randomized, placebo-controlled trial, Anesth. Analg. 108 (2009) 1152-1156.

[55] D.A. Golombek, E. Escolar, L.J. Burin, M.G. Brito Sanchez, D.P. Cardinali, Timedependent melatonin analgesia in mice: inhibition by opiate or benzodiazepine antagonism, Eur. J Pharmacol 194 (1991) 25-30.

[56] P. Govitrapong, S. Sawlom, B. Chetsawang, P. Sangchot, M. Ebadi, The bovine pineal gland contains delta and mu but not kappa or ORL1 opioid receptor subtypes, Proc. West. Pharmacol. Soc. 45 (2002) 32-35. 
[57] R. Hardeland, Antioxidative protection by melatonin: multiplicity of mechanisms from radical detoxification to radical avoidance, Endocrine 27 (2005) 119-130.

[58] R. Hardeland, D.X. Tan, R.J. Reiter, Kynuramines, metabolites of melatonin and other indoles: the resurrection of an almost forgotten class of biogenic amines, J. Pineal Res. 47 (2009) 109-116.

[59] A. Hernandez-Pacheco, C.I. Araiza-Saldana, V. Granados-Soto, T. MixcoatlZecuatl, Possible participation of the nitric oxide-cyclic GMP-protein kinase G-K+ channels pathway in the peripheral antinociception of melatonin, Eur. J. Pharmacol. 596 (2008) 70-76.

[60] F. Hirata, O. Hayaishi, T. Tokuyama, S. Seno, In vitro and in vivo formation of two new metabolites of melatonin, J Biol Chem. 249 (1974) 1311-1313.

[61] A.K. Ho, D.C. Klein, Activation of alpha 1-adrenoceptors, protein kinase C, or treatment with intracellular free $\mathrm{Ca}^{2+}$ elevating agents increases pineal phospholipase A2 activity. Evidence that protein kinase $\mathrm{C}$ may participate in $\mathrm{Ca}^{2+}$-dependent alpha 1-adrenergic stimulation of pineal phospholipase $\mathrm{A}_{2}$ activity, J. Biol. Chem. 262 (1987) 11764-11770.

[62] A.E. Hunt, W.M. Al Ghoul, M.U. Gillette, M.L. Dubocovich, Activation of $M_{2}$ melatonin receptors in rat suprachiasmatic nucleus phase advances the circadian clock, Am. J. Physiol. Cell Physiol. 280 (2001) C110-C118.

[63] S.A. Ismail, H.A. Mowafi, Melatonin provides anxiolysis, enhances analgesia, decreases intraocular pressure, and promotes better operating conditions during cataract surgery under topical anesthesia, Anesth. Analg. 108 (2009) $1146-1151$.

[64] M.F. Jarvis, J.M. Boyce-Rustay, Neuropathic pain: models and mechanisms, Curr. Pharm. Des 15 (2009) 1711-1716.

[65] T.M. John, M.C. Brown, G.M. Brown, An oral melatonin replacement regimen that re-establishes the normal circadian levels of urinary 6-sulphatoxymelatonin in functionally pinealectomized rats, J. Pineal Res. 13 (1992) 145-150.

[66] T.M. John, M.C. Brown, L. Wideman, G.M. Brown, Melatonin replacement nullifies the effect of light-induced functional pinealectomy on nociceptive rhythm in the rat, Physiol. Behav. 55 (1994) 735-739.

[67] S.A. Kanaan, N.E. Saade, J.J. Haddad, A.M. Abdelnoor, S.F. Atweh, S.J. Jabbur, B. Safieh-Garabedian, Endotoxin-induced local inflammation and hyperalgesia in rats and mice: a new model for inflammatory pain, Pain 66 (1996) 373-379.

[68] M. Kavaliers, M. Hirst, Daily rhythms of analgesia in mice: effects of age and photoperiod, Brain Res. 279 (1983) 387-393.

[69] H.K. Kim, S.K. Park, J.L. Zhou, G. Taglialatela, K. Chung, R.E. Coggeshall, J.M. Chung, Reactive oxygen species (ROS) play an important role in a rat model of neuropathic pain, Pain 111 (2004) 116-124.

[70] D.C. Klein, Arylalkylamine N-acetyltransferase: "the Timezyme", J. Biol. Chem. 282 (2007) 4233-4237.

[71] A. Korkmaz, R.J. Reiter, T. Topal, L.C. Manchester, S. Oter, D.X. Tan, Melatonin: an established antioxidant worthy of use in clinical trials, Mol. Med. 15 (2009) 43-50.

[72] D.N. Krause, M.L. Dubocovich, Regulatory sites in the melatonin system of mammals, Trends Neurosci. 13 (1990) 464-470.

[73] M.L. Lakin, C.H. Miller, M.L. Stott, W.D. Winters, Involvement of the pineal gland and melatonin in murine analgesia, Life Sci. 29 (1981) 2543-2551.

[74] C. Laurido, T. Pelissie, R. Soto-Moyano, L. Valladares, F. Flores, A. Hernandez, Effect of melatonin on rat spinal cord nociceptive transmission, Neuroreport 13 (2002) 89-91.

[75] I. Lee, H.K. Kim, J.H. Kim, K. Chung, J.M. Chung, The role of reactive oxygen species in capsaicin-induced mechanical hyperalgesia and in the activities of dorsal horn neurons, Pain 133 (2007) 9-17.

[76] A. Levoye, J. Dam, M.A. Ayoub, J.L. Guillaume, C. Couturier, P. Delagrange, R. Jockers, The orphan GPR50 receptor specifically inhibits $\mathrm{MT}_{1}$ melatonin receptor function through heterodimerization, EMBO J. 25 (2006) 3012-3023. 
[77] A. Levoye, R. Jockers, M.A. Ayoub, P. Delagrange, E. Savaskan, J.L. Guillaume, Are $G$ protein-coupled receptor heterodimers of physiological relevance?-Focus on melatonin receptors, Chronobiol. Int. 23 (2006) 419-426.

[78] A.J. Lewy, J. Emens, A. Jackman, K. Yuhas, Circadian uses of melatonin in humans, Chronobiol. Int. 23 (2006) 403-412.

[79] S.R. Li, T. Wang, R. Wang, X. Dai, Q. Chen, R.D. Li, Melatonin enhances antinociceptive effects of delta-, but not mu-opioid agonist in mice, Brain Res. 1043 (2005) 132-138.

[80] G.A. Lincoln, Melatonin entrainment of circannual rhythms, Chronobiol. Int. 23 (2006) 301-306.

[81] M. Longoni, C. Ferrarese, Inflammation and excitotoxicity: role in migraine pathogenesis, Neurol. Sci. 27 Suppl 2 (2006) S107-S1 10.

[82] P. Lowenstein, E.N. Pereyra, C. Gonzalez Solveyra, D.P. Cardinali, Effect of naloxone on the nocturnal rise of rat pineal melatonin content, Eur. JPharmacol. 98 (1984) 261-264.

[83] P.O. Lundmark, S.R. Pandi-Perumal, V. Srinivasan, D.P. Cardinali, Role of melatonin in the eye and ocular dysfunctions, Vis. Neurosci. 23 (2006) 853-862.

[84] G.J. Maestroni, The immunotherapeutic potential of melatonin, Expert. Opin. Investig. Drugs 10 (2001) 467-476.

[85] G.J. Maestroni, A. Conti, Immuno-derived opioids as mediators of the immunoenhancing and anti-stress action of melatonin, Acta Neurol. (Napoli) 13 (1991) 356-360.

[86] M. Mantovani, M.P. Kaster, R. Pertile, J.B. Calixto, A.L. Rodrigues, A.R. Santos, Mechanisms involved in the antinociception caused by melatonin in mice, J. Pineal Res. 41 (2006) 382-389.

[87] Y.F. Mao, N. Yan, H. Xu, J.H. Sun, Y.C. Xiong, X.M. Deng, Edaravone, a free radical scavenger, is effective on neuropathic pain in rats, Brain Res. 1248 (2009) 68-75.

[88] E. Maronde, J.H. Stehle, The mammalian pineal gland: known facts, unknown facets, Trends Endocrinol. Metab 18 (2007) 142-149.

[89] M.R. Masruha, D.S. Souza Vieira, T.S. Minett, J. Cipolla-Neto, E. Zukerman, L.C. Vilanova, M.F. Peres, Low urinary 6-sulphatoxymelatonin concentrations in acute migraine, J. Headache Pain 9 (2008) 221-224.

[90] A. Mathes, D. Kubuls, L. Waibel, J. Weiler, P. Heymann, B. Wolf, H. Rensing, Selective activation of melatonin receptors with ramelteon improves liver function and hepatic perfusion after hemorrhagic shock in rat, Crit. Care Med. 36 (2008) 2863-2870.

[91] A.M. Mathes, B. Wolf, H. Rensing, Melatonin receptor antagonist luzindole is a powerful radical scavenger in vitro, J Pineal Res 45 (2008) 337-338.

[92] R.F. McGivern, G.G. Berntson, Mediation of diurnal fluctuations in pain sensitivity in the rat by food intake patterns: reversal by naloxone, Science 210 (1980) 210211.

[93] R.A.Meyer, M.Ringkamp, J.N.Campbell, S.N.Raja, Peripheral mechanisms of cutaneous nociception. In S McMahon, M. Koltzenburg (Eds.), Wall and Melzack's Textbook of Pain, 5 th edition Elsevier, London, 2005, pp. 3-34.

[94] G. Mistraletti, E. Carloni, M. Cigada, E. Zambrelli, M. Taverna, G. Sabbatici, M. Ombrello, G. Elia, A.L. Destrebecq, G. Iapichino, Sleep and delirium in the intensive care unit, Minerva Anestesiol. 74 (2008) 329-333.

[95] R.Y. Moore, Vision without sight, N. Engl. J. Med. 332 (1995) 54-55.

[96] R.Y. Moore, Neural control of the pineal gland, Behav. Brain Res. 73 (1996) 125130.

[97] H.A. Mowafi, S.A. Ismail, Melatonin improves tourniquet tolerance and enhances postoperative analgesia in patients receiving intravenous regional anesthesia, Anesth. Analg. 107 (2008) 1422-1426.

[98] C. Muscoli, V. Mollace, J. Wheatley, E. Masini, M. Ndengele, Z.Q. Wang, D. Salvemini, Superoxide-mediated nitration of spinal manganese superoxide 
dismutase: a novel pathway in N-methyl-D-aspartate-mediated hyperalgesia, Pain 111 (2004) 96-103.

[99] M. Naguib, M.T. Baker, G. Spadoni, M. Gregerson, The hypnotic and analgesic effects of 2-bromomelatonin, Anesth. Analg. 97 (2003) 763-768.

[100] M. Naguib, V. Gottumukkala, P.A. Goldstein, Melatonin and anesthesia: a clinical perspective, J. Pineal Res. 42 (2007) 12-21.

[101] M.C. Naranjo, J.M. Guerrero, A. Rubio, P.J. Lardone, A. Carrillo-Vico, M.P. Carrascosa-Salmoral, S. Jimenez-Jorge, M.V. Arellano, S.R. Leal-Noval, M. Leal, E. Lissen, P. Molinero, Melatonin biosynthesis in the thymus of humans and rats, Cell Mol. Life Sci. 64 (2007) 781-790.

[102] F.A. Nelson, L.A. Farr, M. Ebadi, Salivary melatonin response to acute pain stimuli, J. Pineal Res. 30 (2001) 206-212.

[103] O. Nosjean, M. Ferro, F. Coge, P. Beauverger, J.M. Henlin, F. Lefoulon, J.L. Fauchere, P. Delagrange, E. Canet, J.A. Boutin, Identification of the melatoninbinding site $\mathrm{MT}_{3}$ as the quinone reductase 2, J. Biol. Chem. 275 (2000) 3131131317.

[104] T. Ohkubo, M. Shibata, H. Takahashi, R. Inoki, Roles of substance P and somatostatin on transmission of nociceptive information induced by formalin in spinal cord, J. Pharmacol. Exp. Ther. 252 (1990) 1261-1268.

[105] S.A. Onal, S. Inalkac, S. Kutlu, H. Kelestimur, Intrathecal melatonin increases the mechanical nociceptive threshold in the rat, Agri. 16 (2004) 35-40.

[106] S.R. Pandi-Perumal, I. Trakht, G.M. Brown, D.P. Cardinali, Melatonin, circadian dysregulation and sleep in mental disorders, Primary Psychiatry 15(5) (2008) 7782.

[107] C.S. Pang, S.F. Tsang, J.C. Yang, Effects of melatonin, morphine and diazepam on formalin-induced nociception in mice, Life Sci. 68 (2001) 943-951.

[108] S.F. Pang, Q. Wan, G.M. Brown, Melatonin receptors in the spinal cord, Biol. Signals 6 (1997) 272-283.

[109] H. Papezova, A. Yamamotova, J. Nedvidkova, Pain modulation role of melatonin in eating disorders, Eur. Psychiatry 16 (2001) 68-70.

[110] J.K. Paulose, J.L. Peters, S.P. Karaganis, V.M. Cassone, Pineal melatonin acts as a circadian zeitgeber and growth factor in chick astrocytes, J. Pineal Res. 46 (2009) 286-294.

[111] I. Pekarkova, S. Parara, V. Holecek, P. Stopka, L. Trefil, J. Racek, R. Rokyta, Does exogenous melatonin influence the free radicals metabolism and pain sensation in rat? , Physiol Res 50 (2001) 595-602.

[112] M.F. Peres, M.R. Masruha, E. Zukerman, C.A. Moreira-Filho, E.A. Cavalheiro, Potential therapeutic use of melatonin in migraine and other headache disorders, Expert Opin. Investig. Drugs 15 (2006) 367-375.

[113] M.F. Peres, E. Zukerman, T.F. da Cunha, F.R. Moreira, J. Cipolla-Neto, Melatonin, $3 \mathrm{mg}$, is effective for migraine prevention, Neurology 63 (2004) 757.

[114] G.E. Pickard, Circadian rhythm of nociception in the golden hamster, Brain Res. 425 (1987) 395-400.

[115] C.W. Pilcher, S.M. Jones, J. Browne, Rhythmic nature of naloxone-induced aversions and nociception in rats, Life Sci. 31 (1982) 1249-1252.

[116] V. Raghavendra, J.N. Agrewala, S.K. Kulkarni, Melatonin reversal of lipopolysacharides-induced thermal and behavioral hyperalgesia in mice, Eur. J. Pharmacol. 395 (2000) 15-21.

[117] M. Ray, P.K. Mediratta, P. Mahajan, K.K. Sharma, Evaluation of the role of melatonin in formalin-induced pain response in mice, Indian J. Med. Sci. 58 (2004) 122-130.

[118] R.J. Reiter, D. Acuña-Castroviejo, D.X. Tan, Melatonin therapy in fibromyalgia, Curr. Pain Headache Rep. 11 (2007) 339-342.

[119] R.J. Reiter, S.D. Paredes, L.C. Manchester, D.X. Tan, Reducing oxidative/nitrosative stress: a newly-discovered genre for melatonin, Crit. Rev. Biochem. Mol. Biol 44 (2009) 175-200. 
[120] R.J. Reiter, D.X. Tan, Role of CSF in the transport of melatonin, J. Pineal Res. 33 (2002) 61.

[121] R.J. Reiter, D.X. Tan, L.C. Manchester, S.D. Paredes, J.C. Mayo, R.M. Sainz, Melatonin and reproduction revisited, Biol Reprod. 81 (2009) 445-456.

[122] S.M. Reppert, Melatonin receptors: molecular biology of a new family of $G$ protein-coupled receptors, J. Biol. Rhythms 12 (1997) 528-531.

[123] R. Rokyta, P. Stopka, V. Holecek, K. Krikava, I. Pekarkova, Direct measurement of free radicals in the brain cortex and the blood serum after nociceptive stimulation in rats, Neuro. Endocrinol. Lett 25 (2004) 252-256.

[124] R. Rokyta, P. Stopka, E. Kafunkova, J. Krizova, J. Fricova, V. Holecek, The evaluation of nociceptive intensity by using free radicals direct measurement by EPR method in the tail of anaesthetized rats, Neuro. Endocrinol. Lett 29 (2008) 1007-1014.

[125] J.P. Rosenfeld, P.E. Rice, Diurnal rhythms in nociceptive thresholds of rats, Physiol. Behav. 23 (1979) 419-420.

[126] J. Sandkuhler, Models and mechanisms of hyperalgesia and allodynia, Physiol Rev 89 (2009) 707-758.

[127] M. Schmelz, Translating nociceptive processing into human pain models, Exp. Brain Res 196 (2009) 173-178.

[128] A. Schmidtko, I. Tegeder, G. Geisslinger, No NO, no pain? The role of nitric oxide and cGMP in spinal pain processing, Trends Neurosci. 32 (2009) 339-346.

[129] C. Schomerus, H.W. Korf, Mechanisms regulating melatonin synthesis in the mammalian pineal organ, Ann. N. Y. Acad. Sci. 1057 (2005) 372-383.

[130] E.S. Schwartz, H.Y. Kim, J. Wang, I. Lee, E. Klann, J.M. Chung, K. Chung, Persistent pain is dependent on spinal mitochondrial antioxidant levels, J. Neurosci. 29 (2009) 159-168.

[131] S. Shavali, B. Ho, P. Govitrapong, S. Sawlom, A. Ajjimaporn, S. Klongpanichapak, M. Ebadi, Melatonin exerts its analgesic actions not by binding to opioid receptor subtypes but by increasing the release of beta-endorphin an endogenous opioid, Brain Res. Bull. 64 (2005) 471-479.

[132] M. Shibata, T. Ohkubo, H. Takahashi, R. Inoki, Modified formalin test: characteristic biphasic pain response, Pain 38 (1989) 347-352.

[133] A. Slominski, T.W. Fischer, M.A. Zmijewski, J. Wortsman, I. Semak, B. Zbytek, R.M. Slominski, D.J. Tobin, On the role of melatonin in skin physiology and pathology, Endocrine 27 (2005) 137-148.

[134] V. Srinivasan, D.W. Spence, S.R. Pandi-Perumal, I. Trakht, A.I. Esquifino, D.P. Cardinali, G.J. Maestroni, Melatonin, environmental light, and breast cancer, Breast Cancer Res. Treat. 108 (2007) 339-350.

[135] M. Stillman, R. Spears, Endocrinology of cluster headache: potential for therapeutic manipulation, Curr. Pain Headache Rep. 12 (2008) 138-144.

[136] D. Sugden, Psychopharmacological effects of melatonin in mouse and rat, J. Pharmacol. Exp. Ther. 227 (1983) 587-591.

[137] C.S. Sung, C.S. Wong, Cellular mechanisms of neuroinflammatory pain: the role of interleukin-1 beta, Acta Anaesthesiol. Taiwan. 45 (2007) 103-109.

[138] M. Tal, A novel antioxidant alleviates heat hyperalgesia in rats with an experimental painful peripheral neuropathy, Neuroreport 7 (1996) 1382-1384.

[139] D.X. Tan, L.C. Manchester, M.P. Terron, L.J. Flores, R.J. Reiter, One molecule, many derivatives: a never-ending interaction of melatonin with reactive oxygen and nitrogen species?, J. Pineal Res. 42 (2007) 28-42.

[140] N. Toda, S. Kishioka, Y. Hatano, H. Toda, Modulation of opioid actions by nitric oxide signaling, Anesthesiology 110 (2009) 166-181.

[141] H. Tricoire, M. Moller, P. Chemineau, B. Malpaux, Origin of cerebrospinal fluid melatonin and possible function in the integration of photoperiod, Reprod. Suppl 61 (2003) 311-321.

[142] M. Tsuda, A. Mizokoshi, Y. Shigemoto-Mogami, S. Koizumi, K. Inove, Activation of p38 mitogen-activated protein kinase in spinal hyperactive microglia 
contributes to pain hypersensitivity following peripheral nerve injury, Glia 45 (2004) 89-95.

[143] Y. TU, R.Q. Sun, W.D. Willis, Effects of intrathecal injections of melatonin analogs on capsaicin-induced secondary mechanical allodynia and hyperalgesia in rats, Pain 109 (2004) 340-350.

[144] A. Ulugol, D. Dokmeci, G. Guray, N. Sapolyo, F. Ozyigit, M. Tamer, Antihyperalgesic, but not antiallodynic, effect of melatonin in nerve-injured neuropathic mice: Possible involvements of the L-arginine-NO pathway and opioid system, Life Sci. 78 (2006) 1592-1597.

[145] M.I. Vacas, M.I. Berria, D.P. Cardinali, E.F. Lascano, Melatonin inhibits betaadrenoceptor-stimulated cyclic AMP accumulation in rat astroglial cell cultures, Neuroendocrinology 38 (1984) 176-181.

[146] M.I. Vacas, P.R. Lowenstein, D.P. Cardinali, Dihydroergocryptine binding sites in bovine and rat pineal glands, J Auton. Nerv. Syst. 2 (1980) 305-313.

[147] A. Vanotti, M. Osio, E. Mailland, C. Nascimbene, E. Capiluppi, C. Mariani, Overview on pathophysiology and newer approaches to treatment of peripheral neuropathies, CNS Drugs 21 Suppl 1 (2007) 3-12.

[148] H. Wang, C.J. Woolf, Pain TRPs, Neuron 46 (2005) 9-12.

[149] S. Wang, L. Zhang, G. Lim, B. Sung, Y. Tian, C.W. Chou, H. Hernstadt, G. Rusanescu, Y. Ma, J. Mao, A combined effect of dextromethorphan and melatonin on neuropathic pain behavior in rats, Brain Res. in press

[150] S. Wang, L. Zhang, G. Lim, B. Sung, Y. Tian, C.W. Chou, H. Hernstadt, G. Rusanescu, Y. Ma, J. Mao, A combined effect of dextromethorphan and melatonin on neuropathic pain behavior in rats, Brain Res. 1288 (2009) 42-49.

[151] T. Wang, S.R. Li, X. Dai, Y.L. Peng, Q. Chen, R. Wang, Effects of melatonin on orphanin FQ/nociceptin-induced hyperalgesia in mice, Brain Res. 1085 (2006) 43-48.

[152] Z.Q. Wang, F. Porreca, S. Cuzzocrea, K. Galen, R. Lightfoot, E. Masini, C. Muscoli, V. Mollace, M. Ndengele, H. Ischiropoulos, D. Salvemini, A newly identified role for superoxide in inflammatory pain, J Pharmacol Exp. Ther. 309 (2004) 869-878.

[153] S. Xu, W. Wei, Y. Shen, J. Hao, C. Ding, Studies on the antiinflamatory, immnoregulatory, and analgesic actions of melatonin, Drug Dev. Res. 39 (1996) 167-173.

[154] S.W. Ying, Z.Q. Huang, [Effects of the pineal body and melatonin on sensitivity to pain in mice], Zhongguo Yao Li Xue. Bao. 11 (1990) 411-414.

[155] M.H. Yoon, H.C. Park, W.M. Kim, H.G. Lee, Y.O. Kim, L.J. Huang, Evaluation for the interaction between intrathecal melatonin and clonidine or neostigmine on formalin-induced nociception, Life Sci. 83 (2008) 845-850.

[156] C.X. YU, G.C. WU, S.F. XU, C.H. Chen, [Effect of melatonin on release of betaendorphin, norepinephrine and 5-hydroxytryptamine in rat brain], Yao Xue. Xue. Bao. 36 (2001) 5-9.

[157] C.X. YU, B. Zhu, S.F. XU, X.D. Cao, G.C. Wu, The analgesic effects of peripheral and central administration of melatonin in rats, Eur. J Pharmacol. 403 (2000) 4953.

[158] C.X. Yu, C.B. Zhu, S.F. Xu, X.D. Cao, G.C. Wu, Selective $\mathrm{MT}_{2}$ melatonin receptor antagonist blocks melatonin-induced antinociception in rats, Neurosci Lett. 282 (2000) 161-164.

[159] C.-X. YU, S.-M. Weng, C.-H. Chen, Studies on the analgesic effect and physical dependence of melatonin in mice, Chin J Drug Depend 8 (1999) 58-60.

[160] P.K. Zahn, T. Lansmann, E. Berger, E.J. Speckmann, U. Musshoff, Gene expression and functional characterization of melatonin receptors in the spinal cord of the rat: implications for pain modulation, J. Pineal Res. 35 (2003) 24-31.

[161] Q. Zeng, S. Wang, G. Lim, L. Yang, J. Mao, B. Sung, Y. Chang, J.A. Lim, G. Guo, J. Mao, Exacerbated mechanical allodynia in rats with depression-like behavior, Brain Res. 1200C (2008) 27-38. 
[162] J. Zhang, X.Q. Shi, S. Echeverry, J.S. Mogil, Y. De Koninck, S. Rivest, Expression of CCR2 in both resident and bone marrow-derived microglia plays a critical role in neuropathic pain, J. Neurosci. 27 (2007) 12396-12406. 


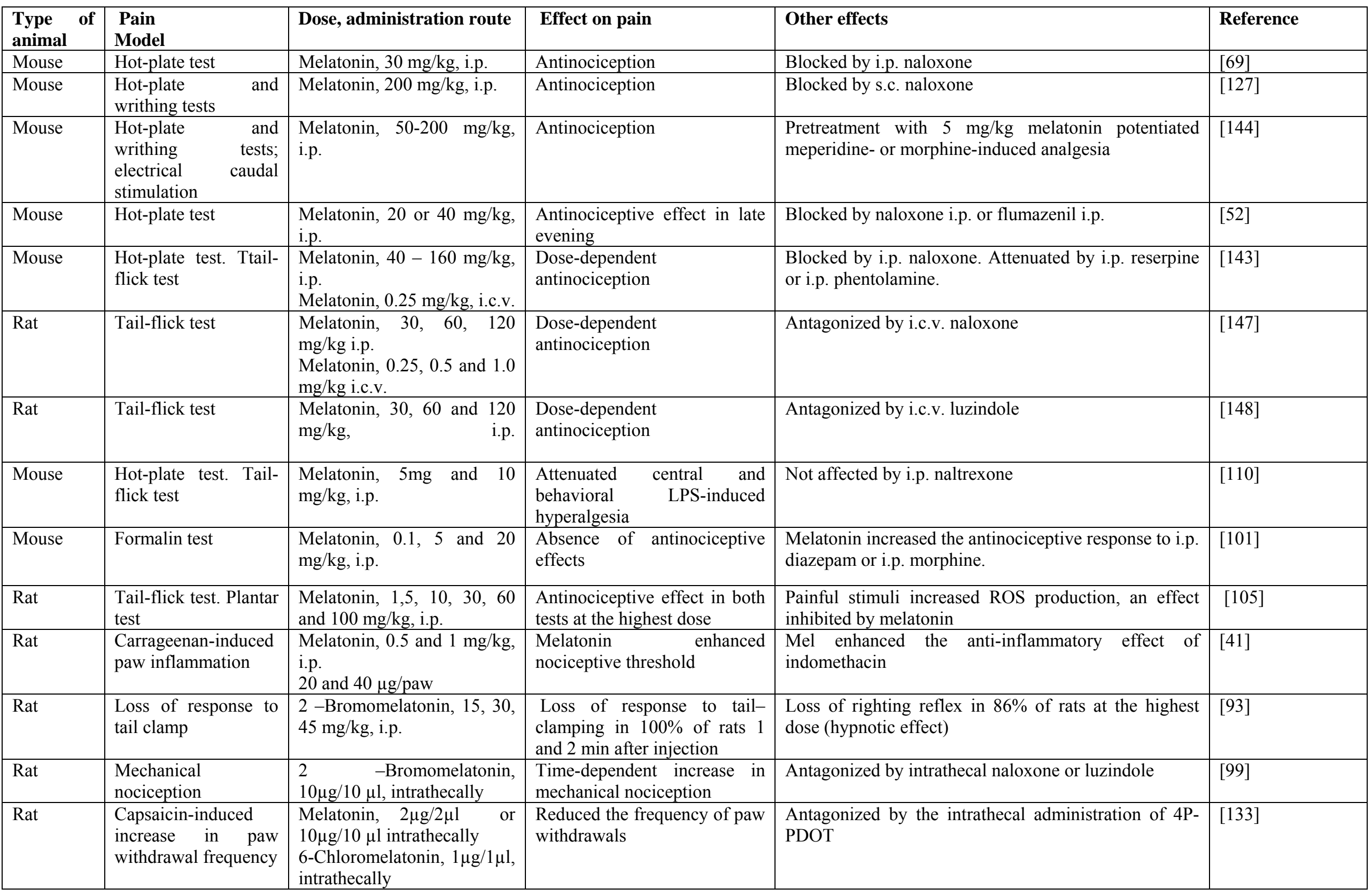


Table 1 (cont.)

\begin{tabular}{|c|c|c|c|c|c|}
\hline Mouse & Tail-flick test & $\begin{array}{l}\text { Melatonin, } 1,5,25 \mathrm{mg} / \mathrm{kg} \text {, } \\
\text { i.p. } \\
\text { Melatonin, } 0.25, \quad 0.5, \quad 1 \\
\mathrm{mg} / \mathrm{kg} \text {, i.c.v. }\end{array}$ & $\begin{array}{l}\text { Enhanced antinociception } \\
\text { given by delta-opioid agonists } \\
\text { but not by mu-opioid agonists }\end{array}$ & Antagonized by i.c.v. luzindole & {$[74]$} \\
\hline Mouse & $\begin{array}{l}\text { Chemical and } \\
\text { behavioral models of } \\
\text { pain }\end{array}$ & $\begin{array}{lrr}\begin{array}{l}\text { Melatonin, } \\
\text { i.p. }\end{array} & 10-100 \quad \mathrm{mg} / \mathrm{kg}, \\
\text { Melatonin, } & 250-500 & \mathrm{pmol} \\
\text { i.c.v. } \\
\begin{array}{l}\text { Melatonin, } \\
\text { intraplantar }\end{array} & 30-100 & \mathrm{ng} / \\
\end{array}$ & $\begin{array}{l}\text { Reduced the neurogenic pain } \\
\text { caused by the intraplantar } \\
\text { injection of glutamate in dose- } \\
\text { dependent manner }\end{array}$ & $\begin{array}{l}\text { The antinociceptive effect of melatonin was completely } \\
\text { prevented by pretreatment of animals with naloxone, } \\
\text { ketanserin, sulpirideL-arginine, yohimbine and } \\
\text { luzindole }\end{array}$ & {$[81]$} \\
\hline Mouse & $\begin{array}{lr}\text { Mechanical } & \text { allodynia } \\
\text { and } & \text { thermal } \\
\text { hyperalgesia } & \text { after } \\
\text { nerve ligation } & \end{array}$ & $\begin{array}{llr}\text { Melatonin, } \quad 30, \quad 60 & , 120 \\
\mathrm{mg} / \mathrm{kg}, & & \text { i.p. } \\
\text { Melatonin, } & 0.001, & 0.01, \\
\text { 0.1nmol, i.c.v. } & \end{array}$ & $\begin{array}{l}\text { With highest doses both i.p } \\
(120 \mathrm{mg} / \mathrm{kg}) \text { and i.c.v. } \\
(0.1 \mathrm{nmol}) \text { reduced thermal } \\
\text { analgesia but not allodynia }\end{array}$ & $\begin{array}{l}\text { L-arginine and naloxone (i.p. or i.c.v.) reduced the } \\
\text { effect of melatonin on thermal hyperalgesia }\end{array}$ & [134] \\
\hline Mouse & Tail-flick test & $\begin{array}{l}\text { Melatonin, } 5,10,50 \mathrm{mg} / \mathrm{kg} \\
\text { i.p. } \\
\begin{array}{l}\text { Melatonin, } \quad 5, \quad 10, \quad 50 \\
\mu \mathrm{g} / \text { mouse i.c.v. }\end{array}\end{array}$ & $\begin{array}{l}\text { Dose-dependent reversion of } \\
\text { hyperalgesia caused by i.c.v. } \\
\text { administration of orphanin } \\
\text { FQ/nociceptin }\end{array}$ & $\begin{array}{l}\text { Efect of melatonin antagonized by i.c.v. naloxone or } \\
\text { luzindole }\end{array}$ & [141] \\
\hline Rat & $\begin{array}{l}\text { Formalin } \\
\text { test }\end{array}$ & $\begin{array}{l}\text { Melatonin, } 10-300 \mathrm{mg} / \mathrm{kg} \text {, } \\
\text { p.o. }\end{array}$ & $\begin{array}{l}\text { Antinociceptive and } \\
\text { antiallodynic effects seen with } \\
\text { a } 150 \mathrm{mg} / \mathrm{kg} \text { or greater dose.. }\end{array}$ & $\begin{array}{l}\mathrm{MT}_{2} \text { receptor antagonist } \mathrm{K} 185 \text { s.c. blocked melatonin- } \\
\text { induced antinociceptive and antiallodynic activity in } \\
\text { diabetic rats }\end{array}$ & [7] \\
\hline Rat & Hot-plate test & $\begin{array}{l}\text { Melatonin pyrrolo[1,2- } \alpha] \\
\text { indole derivatives } 3,5,12, \\
143,5,9 \text { a, } 12 \text {, s.c. }\end{array}$ & $\begin{array}{l}\text { The melatonin pyrrolo[1,2- } \alpha] \\
\text { indole derivatives exerted } \\
\text { more powerful antinociceptive } \\
\text { activity than melatonin. } \\
\text { Activity of compounds } 5 \text { and } \\
12 \text { was highest }\end{array}$ & $\begin{array}{l}\text { The melatonin pyrrolo[1,2- } \alpha] \text { indole derivatives also } \\
\text { exhibited significant anti-inflammatory activity }\end{array}$ & [42] \\
\hline Rat & $\begin{array}{l}\text { Mechanical allodynia } \\
\text { after nerve ligation }\end{array}$ & $\begin{array}{l}\text { Melatonin, } 37.5-300 \mathrm{mg} / \mathrm{kg} \\
\text { p.o. Melatonin, 3-100 } \mu \mathrm{g} \\
\text { intrathecally }\end{array}$ & Dose-dependent anti-allodynia & $\begin{array}{l}\text { Antagonized by intrathecally-administered luzindole or } \\
\text { orally or intrathecally-administered 4-P-PDOT }\end{array}$ & [4] \\
\hline Rat & Formalin test & $\begin{array}{l}\text { Melatonin, } \quad(150-600 \\
\mu \mathrm{g} / \text { paw ipsilaterally applied }\end{array}$ & $\begin{array}{l}\text { Dose-dependent } \\
\text { antinociception }\end{array}$ & $\begin{array}{l}\text { Antagonized by antagonism of the NO-cyclic GMP- } \\
\text { protein kinase G-K }{ }^{+} \text {channel pathway }\end{array}$ & [56] \\
\hline Rat & Formalin & $\begin{array}{l}\text { Melatonin, } 3,10 \text { or } 30 \mu \mathrm{g} \\
\text { intrathecally }\end{array}$ & $\begin{array}{l}\text { Dose-dependent } \\
\text { antinociception }\end{array}$ & $\begin{array}{l}\text { Antagonized by intrathecally-administered luzindole or } \\
\text { 4-P-PDOT }\end{array}$ & {$[145]$} \\
\hline Rat & $\begin{array}{lr}\text { Mechanical } & \text { allodynia } \\
\text { and } & \text { thermal } \\
\text { hyperalgesia } & \text { after } \\
\text { nerve ligation } & \end{array}$ & $\begin{array}{l}\text { Local administration of } \\
\text { melatonin into the } \\
\text { contralateral anterior } \\
\text { cingulate cortex }\end{array}$ & $\begin{array}{l}\text { Melatonin prevented the } \\
\text { exacerbation of mechanical } \\
\text { allodynia }\end{array}$ & $\begin{array}{l}\text { A concurrent improvement of depression-like behavior } \\
\text { was observed }\end{array}$ & {$[151]$} \\
\hline Rat & $\begin{array}{lr}\text { Mechanical allodynia } \\
\text { and } & \text { thermal } \\
\text { hyperalgesia after } \\
\text { nerve ligation }\end{array}$ & $\begin{array}{l}\text { Melatonin, } 30, \quad 60 \quad, 120 \\
\mathrm{mg} / \mathrm{kg} \text {, i.p. }\end{array}$ & $\begin{array}{l}\text { Reduced thermal analgesia but } \\
\text { not allodynia only with the } \\
\text { highest dose }\end{array}$ & $\begin{array}{l}\text { The combined i.p. administration of melatonin ( } 30 \\
\mathrm{mg} / \mathrm{kg} \text { ) and the NMDA receptor antagonist } \\
\text { dextromethorphan effectively reversed both thermal } \\
\text { hyperalgesia and mechanical allodynia }\end{array}$ & [139] \\
\hline
\end{tabular}


